\title{
GENDER PERSPECTIVES:RELATIONSHIPS BETWEEN THE GENDERS IN THE PROFESSIONAL FIELD AND IN THE HOUSEHOLD
}

\author{
I. Miteva*, G. Raykova, V. Kyupova \\ Students, Faculty of Economics, Trakia University, Stara Zagora, Bulgaria
}

\begin{abstract}
In the twenty first century we can freely talk about gender equality in Bulgaria in comparison to other countries in which there is gender discrimination. In modern European societies every woman has the right to education and free choice as provided by law. But is that really true or is there hidden gender discrimination? Do we actually realize what equality means or do we unconsciously accept stereotypes that limit our opportunities? These are the main questions that the present paper seeks to explore. Nowadays women can have a career, but every woman is silently pressured by social gender norms, opinions and stereotypes. Among everything that a modern woman has to deal with, she must also be a housekeeper. Comparing our own survey results with other studies, the paper concludes that in present days, time spent in domestic work increases, compared to the past, and there are various reasons for that. However, women are starting to share their household activities with their partners. Thereby, the roles of men and women in the family are becoming more equivalent.
\end{abstract}

Key words: women, discrimination, stereotypes, equality, society

\section{INTRODUCTION}

In the twenty first century we can freely talk about gender equality in Bulgaria in comparison to other countries in which there is gender discrimination. In modern European societies every woman has the right to education and free choice as provided by law. But is that really true or is there hidden gender discrimination? Do we actually realize what equality means or do we unconsciously accept stereotypes that limit our opportunities?

Of course we cannot claim that men and women are identical. They differ in their physiology, as each person is different in their abilities. We should consider many factors our genetic data, the social environment in which we grew up, education and many others. But we are not talking about similar gender identity, but about equal opportunities and rights in society.

Nowadays, women can have a career, but every woman is silently pressured by social gender norms, opinions and stereotypes. The environment in which we live is a determining factor for our future life. Despite the

\footnotetext{
*Correspondence to: Iskra Ognyanova Miteva, Faculty of Economics, Trakia University 6000, Stara Zagora,Bulgaria,e-mail: iskra93@abv.bg
}

overwhelming evidence of the abilities of women around the world, many are blamed for choosing their profession over procreation. There are typical games for boys and girls from an early child age. Stereotypes unconsciously influence each individual and their solutions over the years. Unfortunately, this is inevitable, but we must not forget that everyone has the right of choice, which should not be determined by anything else except personal desires.

\section{PURPOSE AND METHODS}

The purpose of this paper is to answer some indispensable questions that are rarely discussed in Bulgaria, such as hidden gender discrimination, gender stereotypes and equal rights. These topics are often overlooked and rarely spoken about even in modern society and remain one of the reasons for gender inequality.

Comparing our own survey results with other studies, the paper seeks to give answers to this questions and determines women's place in today's society. In order to do that, we are going to overview consecutively the position of women over the years and nowadays, legislation regulating gender equality, the position of working women and women as 
mothers, the endless circle of poverty and stereotypes for some women, domestic labor, mens' position in the modern family and compare them to our survey results.

A quantitative empirical survey was conducted by means of a standardized questionnaire among 30 women in December 2014 before Christmas in the village of Gabarevo, Pavel Banya Municipality, Stara Zagora region, in a residential building in Stara Zagora and Trakia University. For the purpose of the study, the respondents involved were 25 women from Stara Zagora and 5 women from the village of Gabarevo, 19 from which with higher education, 2 with college education and 9 with secondary education. The surveyed women were between age 30 to 55 . Two of them were divorced (one of which with a child), 4 single and 24 married (with children). The survey consists of 15 questions and aims to unveil women's opinion on their social place in modern society.

\section{THE POSITION OF WOMEN OVER THE YEARS AND NOWADAYS}

According to different researches, the position and attitude towards women has changed dramatically over the years. For a long time, the ancient tradition treated women as legally and socially equal to slaves, children and foreigners. This continued until the modern age, when the idea of women's rights and place in society slowly began to change. Medieval culture developed the idea that women are subordinate to men and contributed to the development of stereotypes about gender roles and further demonization of women. In the Renaissance period, there was less hatred towards women, but they were still considered unequal to men. In the $18^{\text {th }}-19^{\text {th }}$ century, there seemed to be more lenient, mocking attitude towards the "fairer" sex, but the acrimony towards smart women continued to exist.

An important part in the history of women's rights concerns the recognition of girls' education. The idea was discussed at the beginning of the $15^{\text {th }}$ century, when the socalled "Arguing for women" dispute took place in France. The question was whether women are inferior beings, equal to or surpassing men. Their place in society was still undefined, neither were their rights. Women didn't even have the right to education. Only in 1686 the first public school for girls, "Saint-Cyr," was founded in France, which was a privilege reserved for the upper class. The emphasis was on educating women because of the social and cultural role mothers played in upbringing their children. This thinking and approach to education of the "fairer" sex is still very widespread in some countries, even though this is something that we can hardly believe.

It was during the Age of Enlightenment that equality between men and women was taken under consideration. The fact that women began to be viewed outside the boundaries of the family, home economy, household chores and home education proves this. They weren't just housewives anymore, but something more. Their place in society was hard to determine and only around the Age of Enlightenment a compromise was reached, creating the socalled "utilitarian ideal" of female education and upbringing, which was dominant in Europe until the 20th century. According to ideal, a woman was not considered a separate person, but because of her roles as a housewife, mother and educator, she was given the right to study for such.

The idea of women's education received new impetus with the Industrial Revolution in the early $19^{\text {th }}$ century. Around that time, the mechanisms of social control in the old type of family, where girls were satisfied with their cultural stereotypical roles were torn, and women began to seek realization outside their housework. Because of the more active role played by women, the need for organizations to protect their rights emerged. Since then and until nowadays, women's movements have been striving for equal educational rights for women, for increasing the opportunities for wage labor, for equal wages, reforms in civil law and putting an end the double "gender standard" and prostitution, for political rights and the purely biological right of abortion and family planning.

Bulgaria remained away from such developments, for objective reasons, but undoubtedly followed the footsteps of Western countries. The attitude towards women's education in Bulgaria was undoubtedly influenced by ancient, medieval and Christian traditions, by lagging modernization in society and the oriental tradition, which helped in forming the subordinate position of women to men and their subservient public life. Gradually, Bulgarian women began to be treated not only as the guardian of the hearth, but as capable of being equally educated with men. The process of founding women's associations in Bulgaria was different from that in the West, because Bulgarian girls' education preceded feminism. The education of Bulgarian women remained divided and did not have equal status with men's schools, as they differed in their curricula until the 
beginning of the $20^{\text {th }}$ century. The factors that boosted girls' education after the Liberation were various, but they were still just the beginning. Despite the existing legislative measures, it proved extremely difficult to change public opinion, which along with the changes in the right to education, are the main steps towards gender equality (1).

Throughout history the gender perspectives were also influenced by the political systems. Socialism, as a political system, affects the social thinking and gender stereotypes. According to the Constitution from 1946, women and men had equal rights and child care was taken up by the state. Even though women had rights on paper, there existed the so-called "double workload", "double existence" and "double projection" of things in the communist states, which explained the fact that equality was only formal, and actually, this same equality put women in a very disadvantageous social position. Women had and still have to be mothers, good wives, housekeepers and equally efficient to men. (2) This is the so called "overworking of the woman". (3) Even after the fall of communism in Bulgaria, women remained mostly engaged in domestic work and employed in highly feminised sectors. (4) Fotev calls this the "internalisation of the female subordinate position ", which means that women choose typically "female" professions, which don't "seem coercive" but "natural" to them. (5 and 4) Education and legislation are some of the main factors determining gender equality, but they are not the only ones. The influence of the society and the cultural and social area in which we live is really powerful. Even in the $21^{\text {st }}$ century we can hardly say that there is a real equality between men and women - by law they are equal, but in reality "the fairer sex" is still limited and put in "frames" in terms of behavior.

\section{LEGISLATION REGULATING EQUALITY}

The legislation is a leading factor in the fight for women's presence in the professional area. The first Equal Pay Act was adopted in the United Kingdom in 1970. It defined as illegal the different payment of men and women for the same work. Unfortunately, this act wasn't really respected, so in 1975, the European Community introduced a stricter law on equal pay. It states that not only "equal work," but "work which attributes equal value" should be rewarded evenly. In comparison, in Bulgarian legislation there is a "Law on Equal Opportunities for Women and Men", which is supposed to enact gender equality.
Unfortunately, this law contradicts itself and allows "favoring of one sex over the other." (6) The main source of women's rights of equal education and professional realization is the Law on Protection against Discrimination. It prohibits any direct or indirect discrimination based on sex, race, nationality, ethnicity, origin, religion or faith, education, beliefs, political affiliation, personal or public status, disability, age, sexual orientation, marital status, property or any other features established by the law or international treaty to which Bulgaria is a party. (7) The right to receive complaints, to carry out an independent investigation, to impose sanctions and to issue provisions in case of discrimination has the Commission for Protection Against Discrimination.

Also the issue of equal treatment of women and men is settled in each code that affects the rights of women and settles gender relations Labour Code, The Code of Medical Ethics, The Code of Dentists and The Lawyer's Code of Professional Responsibility, as well as in the Education Act. It is these laws that should regulate the position of women in the professional area, Bulgaria, as a member of the EU, has adopted a number of its own laws and regulations that settle gender equality. The European Union has adopted 5 main directives, conducting such equality in various fields:

- Directive since 1975 - aiming for approximation of the laws in the Member States regarding the principle of equal payment of men and women workers (75/117 / EEC);

- Council Directive since 1976, which is related to equal treatment of men and women in terms of access to employment, education, career advancement and working conditions (76/207 / EEC);

- Council Directive since 1997 regarding the proof of cases of gender discrimination (97/80 / EC);

- Council Directive since 2000 regarding the application of the principle of equal rights of people from different races and ethnicities (2000/43 / EC);

- Council Directive since 2000 defining the general framework for equal work and employment treatment (2000/78 / EC);

Also there are a number of European conventions and our country is obligated to observe and apply them. (8) No matter how comprehensive and in helpfulthe legislation is, unfortunately, it does not guarantee that discrimination or gender inequalities will not occur. Stereotypes and established norms often have more leading role than the legislation and qualifications of the individual. The gender perspectives and social environment can 
influence careers and the family environment. Nowadays, this influence has decreased, but it is still highly determinative.

\section{THE WORKING WOMAN}

Until recently, paid work in Western countries was mainly a field for men. In recent decades, this situation has radically changed: more and more women are economically active, but the proportion of employed women continues to be less than that of men.

Today, in most European countries, around 35 to $60 \%$ of women aged between $16-60$ years have a job besides their housework. Unmarried women have the most significant increase. The level for the UK is $53 \%$. Over $40 \%$ of married women with children under three years of age have a paid job. But the relative share of employed women continues to be less than that of men: $74 \%$ of the male population aged between 25 and 60 years has a paid job. (6)

European Statistics in 2013 showed that there is still a division between genders. Workers from 15 to 64 years divided by gender are the following: in Germany working women in 2003 were $68.8 \%$ and men - 77.7\%; in France working men were $67.9 \%$ and the percentage of women was $60.4 \%$; in Greece $40.1 \%$ were the working women and $58.4 \%$ - men; in Turkey, where workers retire early, compared to Bulgaria, the percentage of working women was only $29.6 \%$, and the jobs occupied by men were $69.5 \%$. We surpass Greeks a little and have almost reached the percentage of Franceworking men in Bulgaria are $62.1 \%$ and the percentage of women is $56.8 \%$. (9)

Table 1. Employment rates by sex, age group 15-64, $2013 \%$

\begin{tabular}{|l|l|l|}
\hline & Male & Female \\
\hline EU-28 & 69.4 & 58.8 \\
\hline Euro area (EA-18) & 68.8 & 58.3 \\
\hline Sweden & 76.3 & 72.5 \\
\hline Netherlands & 78.7 & 69.9 \\
\hline Germany & 77.7 & 68.8 \\
\hline Denmark & 75 & 70 \\
\hline Austria & 77.1 & 67.6 \\
\hline United Kingdom & 75.6 & 65.9 \\
\hline Finland & 69.9 & 67.8 \\
\hline Estonia & 71.4 & 65.7 \\
\hline Czech Republic & 75.7 & 59.6 \\
\hline Luxembourg & 72.1 & 59.1 \\
\hline Latvia & 66.8 & 63.4 \\
\hline France & 67.9 & 60.4 \\
\hline Lithuania & 64.7 & 62.8 \\
\hline Slovenia & 67.1 & 59.2 \\
\hline Belgium & 66.4 & 57.2 \\
\hline Cyprus & 67 & 56.9 \\
\hline
\end{tabular}

\begin{tabular}{|l|l|l|}
\hline & Male & Female \\
\hline Bulgaria & $\mathbf{6 2 . 1}$ & $\mathbf{5 6 . 8}$ \\
\hline Hungary & 64.3 & 52.8 \\
\hline Italy & 64.8 & 46.5 \\
\hline Spain & 59.2 & 50.3 \\
\hline Greece & 58.4 & 40.1 \\
\hline Croatia & 52.8 & 45.6 \\
\hline Iceland & 83.2 & 79 \\
\hline Switzerland & 84.6 & 74.4 \\
\hline Norway & 77.3 & 73.5 \\
\hline Japan (2) & 80.3 & 60.7 \\
\hline United States (2) & 72.3 & 62.2 \\
\hline Turkey & 69.5 & 29.6 \\
\hline FYR of Macedonia & 54.5 & 37.3 \\
\hline Portugal & 64 & 58.2 \\
\hline Malta & 74.1 & 47 \\
\hline Ireland & 65.1 & 55.9 \\
\hline Poland & 66.6 & 53.4 \\
\hline Slovakia & 66.4 & 53.4 \\
\hline Romania & 66.8 & 52.6 \\
\hline
\end{tabular}

Used source for Table 2. Employment rates by sex, age group 15-64, 2013(9)

Women can't reach the level of employment of men yet, because there is still a division between the genders. Opportunities for the women are small, as they are associated with their duties as mothers.

Nowadays, working women are concentrated in poorly paid, routine professions. The

question whether women are mothers or not has a great impact on women's participation in paid employment. Women without children work full-time in most cases, while women who have children and household responsibilities often work part-time. Currently, women who have economic success must fit into a world, in which they don't feel completely accepted. The experiences of women leaders can be compared with the experiences of people who have gone to 
another country. In the long term, however, women might cause a change in male values, achieving synchronization between family responsibilities and work demands.

One of the main factors influencing the career of women is the male's conception that for women work is on second place. When starting work, almost all women are asked whether they have or plan to have children. This is because some employers think that this fact will interfere with woman's work. In fact, the few women who have held senior positions were without children and some of those who were planning to have children in the future, said that they intend to leave the workplace and then possibly to retrain for another post. In a survey held among 200 women, they all pointed out the problem with the children as an obstacle to success in working life. (6)

\section{THE WOMAN AS A MOTHER}

Today, more and more women are trying to deal with both things simultaneously. Besides being a mother, today's woman should be also an equal partner in the family e.g. not to forget her career and to have the ambition to construct it. Because of this, every young mother sooner or later asks herself: "When to go back to work? „The realities in Bulgaria are such that a family can hardly subsist on one salary. But every mother must be asking "How can I leave my child and go to work? "Is it possible to have a balance between career and motherhood?

When a woman becomes a mother her life changes completely. She no longer goes to work and gives all of her attention, care and tenderness to the child. In front of her eyes it has changed from a helpless baby to a grownup person that can walk, attempts to speak and express himself/herself. She has discovered the power of maternal love and realized that this is the love of another, higher level.

But there are moments when she thinks with nostalgia of the past, when she could do whatever she wanted without stealing from the moments with her child. She discovers that she misses the dynamics of the workplace, the contacts with her colleagues and long lunches in some pizzeria. Let's not forget the sweet moment when receiving her monthly salary or praise for a job well done. Few people realize that maternity is work 24 hours per day, without weekend and holiday. Like every job, it exhausts and burdens a woman with responsibilities. When a woman is raising her child alone, it is very difficult for her to find time for simple things like shopping, going to the hairdresser, reading a new book or spending an entertaining night out. It is clear that individual needs and requirements shouldn't be overlooked, because each woman wants to be beautiful, informed and to feel complete. (10)

\section{THE VICIOUS CIRCLE OF POVERTY AND STEREOTYPES FOR SOME WOMEN}

Ultimately every woman asks herself: "Why am I paid worse than my male colleagues, provided that I am mother and I am doing my job well? Why incomes are different for men and women for one and the same work? Why women have lower socio-economic status, provided that they are doing their job as good as men?"

The report on the labor market and women, which was announced at the 14th international trade union women's conference of the International Trade Union Confederation (ITUC) / Pan-European Regional Council (PERC), which was held on October 23- 24, 2013 in Hotel "Rodina" in the town of Sofia, established that the low socio-economic status of women is due to their lower earnings and less favorable positions in the workplace. The majority of the female population is below the limit of poverty. This gives rise to talk about the feminization of poverty, which in recent years has deepened in scope. Of the total number of women, $23.6 \%$ live in poverty and social exclusion, while in 2006 this percentage was 19.3.

From the report prepared by Violeta Ivanova expert at the Institute for Social and Trade Union Research CITUB, it is clear that the share of low-wage workers represent one third of all employees of the Bulgarian labor market. About $2 / 3$ of them are women, whose wages are $75 \%$ lower than the amount of the average salary (as of March 2012). The problem of poverty among women is obvious. (11)

The unions account that women must be granted the same outlets, which are available to men, while taking into account their specific needs arising as to the nature of the sector in which they operate and the need for balance between professional and personal development life. Yet, women are often faced with the choice: career or family, according to the Confederation. (12) Despite the efforts of women to be good, both at work and family life, they continue to be associated primarily with the family.

\section{DOMESTIC LABOUR}

Each of us is part of a household. Society is built up on the basis of a set of households that 
resemble bricks, constructing a building. When these bricks are strong - the building is sustainable. For this reason, households are really important to society and are object of research of both economists and sociologists.

The household, discussed in a narrow sense, is "an area of employment, in which the members of the family (or clan) support by their labor the personal needs of this family in the form of natural products or services".

Neoclassical economic theory makes a strict distinction between the area of production, which includes various companies, and the area of consumption, which includes households. The first is oriented to making a profit, and the second - to maximize the usefulness. (13)

In the past, production activities were performed at home or very close to the home. This changes with the development of the industry - the workplace is separated from home and becomes a place rather for the consumption than for the production of goods. Domestic work becomes "invisible," while as a real job is considered one that gives direct payment. However, paid work was mostly the field for men, while women had to cope with housework and raising children. Common stereotypes are that the place of women is at home, while men are those who work out of the home for a fee.

Work in the household was extremely difficult before the inventions and conveniences affected the domestic area. Due to the lack of running water in homes, women had to carry water for miles and warm it up whenever they needed hot water. The installation of hot and cold running water in their homes eliminated this inconvenience. Homes were electrified, labor-saving devices were invented (e.g. washing machines, vacuum cleaners). Despite significant reliefs in households, the average amount of time that women spend on household work has not changed significantly. New obligations arise to replace the old. The time women spend on shopping, cooking and childcare increases.

The unpaid domestic work is very important for the economy. It forms between 25 and $40 \%$ of the industrialized countries' wealth. The housewives are also not included in the unemployment figures, although they don't have gainful employment. They are part of the so-called "hidden economy" of the different countries. (6)

According to a research on time budget of the population, conducted by the National
Statistics Institute in 2001/2002, people spend a significant amount of time during the day for housework.

Average women spent almost 4,5 hours for household chores every day, while men spent much less time - about 2,5 hours. Most of the time is spent on cooking, dishwashing and cleaning. There are significant differences between the two sexes in these activities. There is minor difference between men and women only in shopping. (14)

\section{MEN'S POSITION IN THE MODERN \\ FAMILY}

The role of men in the modern family is the subject of increased interest for sociologists. In recent years, a number of demographic, socioeconomic and cultural changes have occurred, as a result of which the role of men played in the family has changed. Although the woman is still the one that mainly takes care of the household and raises children, more and more men begin to do household chores, take care of their children and provide emotional support to their wives.

We can make a description of the so-called "new father" and "new husband". The "new father" participates in household chores, attends childbirth classes and classes for raising children with his wife, takes care of the children more actively, takes paternity leave and is well educated; the "new husband" has a smaller role in the maintenance of the family, is caring and more empathetic to the problems of his wife and children.

A number of sociological studies in connection with the place of man in the family have been made. A study was conducted in 2012 by the project "Active fatherhood" which is part of foundation "Applied Research and Communications". The results of it show that the patriarchal family model is gradually dying out to be replaced by equal relationships, in which both partners share the burden. In Bulgaria, more and more men take care of raising their children. Nearly 1300 fathers took paternity leave in 2011 , which is $30 \%$ more than their number in 2009. The number of fathers, who are willing and insist on custody in divorce cases, has also increased. According to the respondents, the most important roles of the father are to be protector of the family and to provide material security. (15)

In 2014 there was a survey with the topic "Attitudes, practices and barriers in front of active male involvement in child care". The results of show that the image of the father ,who is involved in every day child's and home 
care and who expresses his emotions is strongly supported. About $97 \%$ of the parents who took part in the survey agree that the most important decisions related to the child should be taken jointly by the mother and father. (16)

\section{SURVEY RESULTS}

The results from the conducted survey show that among the 30 surveyed women, 18 of them defined their social status as bad, and the rest 12 defined themselves as part of the middle class. (Error! Reference source not found.)

28 of the surveyed are employed and 2 of them are students. (

Figure 2. Social group)

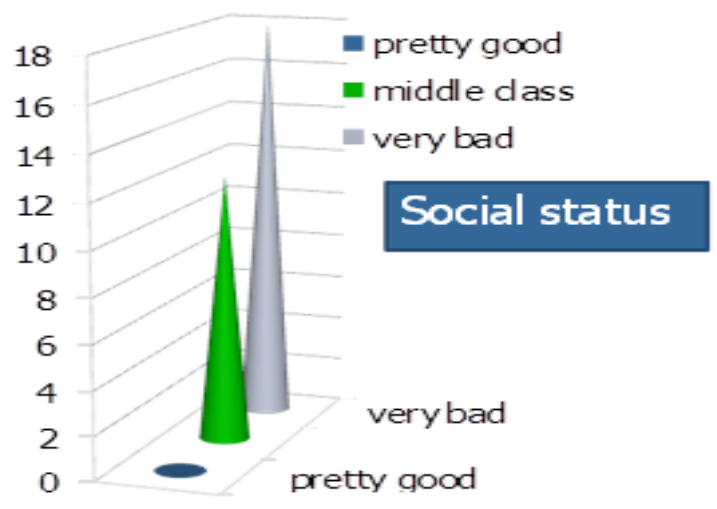

Figure 1. Social status of the surveyed

\section{Social group}

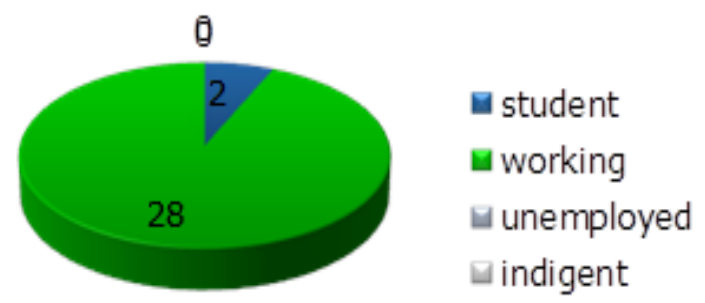

Figure 2. Social group

27 of the women confirmed that in a job interview their employer asked them if they have or plan to have children. (Error! Reference source not found.)

Answers: During a job interview you, have you been asked the questions: "Do you have children" or "Do you intend to have children?"

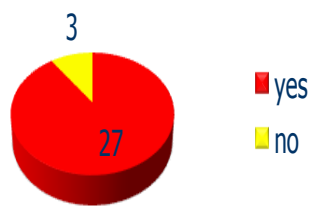

Figure 3.

\section{the extent to which a man is involved in housework}

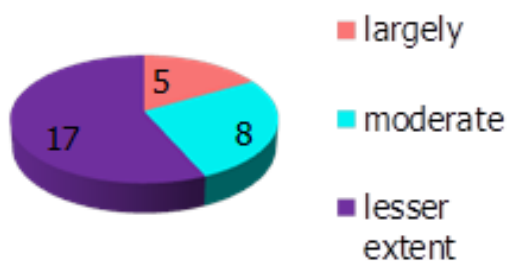

Figure 4. The extent to which a man is involved in housework

The same women gave positive answers to the question whether they can cope with their work, provided that they have a family. One of the surveyed women at the age of 34 added a question she had been asked: Do you intend to return to the same position after your maternity leave?

Most of the surveyed women shared that their husbands helped them with household activities to a very small extent and only 8 women said that their husbands helped them to a moderate extent. Most of the surveyed answered that they disagreed with the following statement: "Traditionally the role of the father in the family is to earn money and the role of the mother - to take care of the home." (Figure 5)

Question: Do you agree with the following statement: "Usually, the role of the father in the family is to make money, and the mother - to take care of the home"

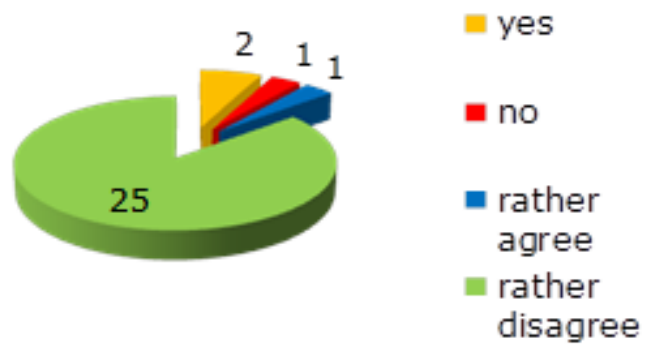

Figure 5.

The surveyed women were most excited by the last question in the survey: in what they would like to receive more help in housework from their husbands, and added various answers to it, such as:

- „To help me more with childcare“

- „Sometimes he can run the vacuum cleaner"

- „Help with shopping“

- „To wash the dishes more often “ 
MITEVA I., et al.

- „I won't be angry, if he surprises me with a dinner"

- „To take out the trash“
- „, To hang out or at least to remember sorting the laundry“",Sometimes he can come and pick me up from work, when I'm tired" (Error! Reference source not found.)

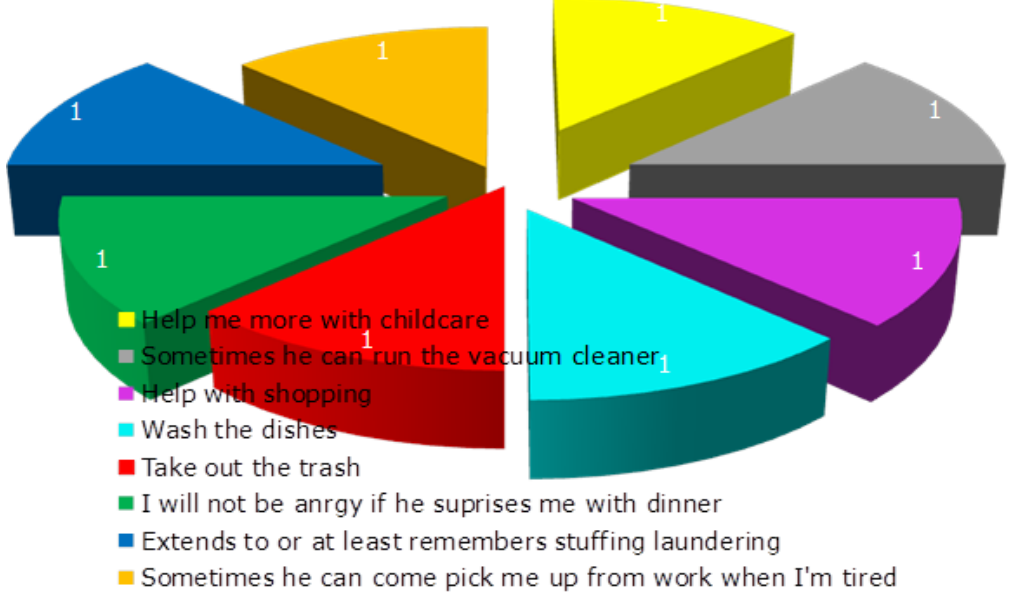

Figure 6.

\section{CONCLUSION}

It has been a long way for women to overcome much of the stereotypes in society and to acquire the rights and opportunities they have today. Gender equality is the result of the long and hard work of thousands of women, who gave their lives in the struggle for justice and democracy. Over the years, comprehensive laws assuring equality between men and women have been enacted. In recent years, the roles of men and women in the family have become more equal, and men more actively join in household activities and child upbringing.

Despite everything, however, there are still problems with inequalities in different areas of public life - education, politics, employment, or in private life. The key to the solution of equality lies in ourselves - we need to unite to fight with the stereotypical ways of thinking and prejudices in society. Because men and women are not physiologically identical but must have the same status and rights in society.

\section{REFERENCES}

1. Nazarska, Zh., University education and Bulgarian women 1879- 1944. Imir: Sofia, 2003.

2. Koceva, T., Todorova I., The Bulgarian Woman - Traditional Images and Changing Realities. Krakra, 1994.

3. Stoilova, R., Gender stratification: Influence of gender on stratification in Bulgaria after 1989. Ciela: Sofia, 2012.

4. Darakchi, Sh. "Bulgarian Gender Research in Sociology." ISSK, BAS, Bulgarian Science Journal, 03/05/2014. (http://nauka.bg)

5. Fotev, G., Stoilova, R., Women: Justice Today. Kota, Sofia, 2000.
6. Giddens, A., Sociology. "Prozorets": Sofia, 2003.

7. Law on Protection against Discrimination, Prom., SG 86 of 30.09.2003, effective from 1.01.2004., Item 1, Q.3, №171, National Council for Cooperation on Ethnic and Demographic Issues, (http://www.ncedi.government.bg)

8. Legislative regulation of equal opportunities for women and men in European countries and the USA, January 2006, National Assembly of the Republic of Bulgaria, Student Program for Legislative Research, (http://www.parliament.bg)

9. Employment data (www.epp.eurostat.ec.europa.eu)

10. Nikolova, K., "Housewife, mother, career woman ... What is the choice of today's woman?" Charitable association "Bulgarian Baby Center". (www.biberonbg.com)

11."Living Standards - Nearly $1 / 4$ of working women living in poverty and social exclusion.," Confederation of Independent Trade Unions in Bulgaria (CITUB), 23 October, 2013. (www.knsb-bg.org)

12. Madanska, D., "Working women in the country". 01.08.2014. (www.econ.bg)

13. Radaev, V.V., Economic Sociology. Lectures. Aspent Press: Moscow, 1998.

14. National Statistical Institute, "Time budget 2001/2002". (www.nsi.bg)

15. Shahbazyan L., "Attitudes towards fatherhood in Bulgaria". "Applied Research and Communications" Foundation. 2012. (http://mencare.bg)

16.Petrov D., "Attitudes, practices and barriers to active male involvement in child care". National Campaign "To Be A Father", 2014. (http://mencare.bg) 